\title{
Северокорейская ракетно-ядерная программа с точки зрения теории секьюритизации
}

\begin{abstract}
Введение
Настоящее исследование направлено на применение положений теории секьюритизации к изучению северокорейской ракетно-ядерной программы для выяснения фракторов, повлиявших на её развитие в начале XXI в., а также прогнозирования возможных вариантов развития событий с учётом недавних событий. В современности данная проблема является одной из ключевых сразу на нескольких уровнях безопасности: локальнол/субрегиональнол (захватывающим соответственно Корейский полуостров и Северо-Восточную Азию), региональнол (в рамках Азиатско-Тихоокеанского региона в целом) и глобальнол (затрагивающим интересы внерегиональных игроков за счёт совершенствования северокорейских технологий межконтинентальных баллистических ракет). В российских условиях актуальности теме придаёт непосредственное соседство с КНДР, которая даже при отсутствии открытых военных действий оказывает дестабилизирующее влияние на обстановку в регионе ракетными пусками и ядерными испытаниями.

С точки зрения регионального измерения данная проблема является определяющей для безопасности Северо-Восточной Азии как для внутрирегиональных игроков, так и для внешних акторов, в частности США [5, с. 3]. Наряду с тематикой иранской ядерной программы, северокорейская проблематика занимает центральное место в современных исследованиях, посвящённых режиму нераспространения ядерного оружия.

Стоит отметить неразрывную связь ракетной и ядерной программ КНДР, так как эфорективное применение ядерного оружия зависит от наличия соответствующих средств доставки (например, ракет малой и средней дальности и МБР). Кроме того, секьюритизация проблематики противоракетной обороны (в частности, в Азиатско-Тихоокеанском регионе) происходит в непосредственной привязке к "странам-изгоям" [11, с. 162]. Это и обусловило рассмотрение ракетно-ядерной программы Северной Кореи в качестве единого целого в данной статье.
\end{abstract}

\section{Теоретико-методологические основы исследования}

Теория секьюритизации, выдвинутая американским экспертом Б. Бузаном в рамках дискуссии с неореалистами и в дальнейшем разработанная в рамках Копенгагенской школы О. Вевером ещё в 1980-е гг., считается одной из наиболее успешных критических теорий международных отношений. Фундаментом настоящей теории считается схема, согласно которой определённая проблема для начала проходит этап политизации (т. е. широкое обсуждение в средствах массовой информации и на общественных площадках), а затем подвергается секьюритизации (под которой понимается объявление такой проблемы экзистенциальной угрозой). Одним из основных положений указанной теории является объяснение появления такой угрозы международной безопасности как публичного речевого акта объявления её таковой со стороны крупного игрока (прежде всего, государства). Такой акт становится спусковым механизмом легитимизации отхода от старых правил [15, с. 12]. В таких выступлениях, как правило, используются определённые словесные

ТОРОПчИН Глеб Вячеславович, канд. ист. наук, доцент кафедры иностранных языков технических факультетов Новосибирского государственного технический университета (2. Hовосибирск). E-mail: glebtoropchin@mail.ru 
маркеры ("опасный", "угрожающий" и т. п.), которые характеризуют действия другого актора международных отношений. Используются так называемые бинарные оппозиции, позволяющие адресату таких речевых актов чётко различать и противопоставлять себя и противника. Особенно эфрфективным приёмом в этой связи является обращение к предыдущему негативному опыту, а также использование авторитетных специалистов (представителей экспертного сообщества) и властных структур. После такой подготовки дальнейшие действия (в том числе и агрессивные) в отношении источника указанной угрозы представляются обществу и другим участникам международного процесса логичными и последовательными.

Обратным процессом авторам теории видится десекьюритизация проблемы, т. е. её откат к status quo во многом за счёт косвенных фракторов. При этом таковая зачастую расценивается положительно [26, с. 57], так как она восстанавливает нарушенный баланс в международных отношениях и снижает риски перехода к военному сценарию. Десекьюритизация, таким обра3ом, приводит к изменению фокуса повестки дня на мирное строительство [15, c. 12].

Теория секьюритизации является одним из успешно апробированных инструментов для анализа и объяснения региональных процессов при учёте глобального контекста. Действительно, Б. Бузан и О. Вевер, разработавшие теорию секьюритизации, оперировали в том числе ключевым понятием "регионального комплекса безопасности". Подразумевается значительное влияние территориально-географического фрактора на оценку угроз безопасности, что ведёт к регионализации рассматриваемых проблем. В данном случае речь идёт об азиатском комплексе безопасности или, если брать более точное географрическое определение, таком субрегионе, как Северо-Восточная Азия.

Считается, что теория секьюритизации отчасти продолжает традиции школы политического реализма. Как отмечает Д.И. Победаш, по мнению реалистов, признающих примат государства как основного актора, легко объясняется решение КНДР реализовать своё право на выход из Договора о нераспространении в 2003 г. [8, с. 23]. С точки зрения применения классических теорий международных отношений (в частности, политического реализма) на первое место выходит весьма непростой вопрос о рациональности Северной Кореи как актора международного процесса. В риторике западных СМИ и англоязычном научном дискурсе "агрессивность" северокорейской внешней политики зачастую подменяется понятием "иррациональность". На самом деле существует определённая предсказуемость флуктуаций поведения Пхеньяна, которое зависит от внешних и внутренних фракторов: обстановки в мире и регионе, экономической ситуации в стране, объективных достижений научно-технического прогресса. Рациональность северокорейских элит выражается в их стремлении к сохранению суверенного государства в текущем виде, поиска защиты от экзистенщиальных угроз в условиях хаоса и анархии современных международных отношений. Примеры влияния схемы секьюритизации Соединёнными Штатами ситуации в других странах, ранее обвинённых в разработке ОМУ (Ирак, Ливия), также оказывают влияние на поведение КНДР. И напротив, это противоречит положениям неолиберального институционализма, который во главу угла ставит международное сотрудничество, реализуемое путём работы международных организаций и действия договоров. Тем не менее углубление повестки безопасности не означает того, что круг международных акторов ограничен государствами. Напротив, он расширяется за счёт организаций, групп влияния и даже фризических лиц [11, с. 39]. Это соответствует современной тенденции на более пристальное внимание к роли личности в мировой политике. Наряду с этим можно встретить мнение, что секьюритизация ядерной политики КНДР со стороны США и Запада происходит в рамках либерального капитализма [21]. По мнению М. Поттса, с точки зрения секьюритизации переговоры с КНДР бесполезны, так как интересы Северной Кореи расходятся с устремлениями мирового сообщества. Выполнение Пхеньяном международных обязательств видится в этой парадигме как спорадическое.

В то же время нельзя отрицать, что теория секьюритизации тесно связана с другим направлением в исследовании международных отношений - социальным конструктивизмом. Международные отношения представляются 
как продукт деятельности лиц, ответственных за выстраивание внешней политики государств. В частности, ключевую роль в данном отношении играют речевые акты таких лиц, т. е. вербализованные определения в адрес потенциальной угрозы.

Применение других критических теорий международных отношений (а именно: эмансипации, инсекьюритизации) к рассматриваемому вопросу также представляется возможным, однако ввиду их большей гуманизации и концентрированности на индивиде как акторе международного процесса [9, с. 185-186], очевидно, было бы менее успешным.

\section{Степень изученности темы}

Тематика ракетно-ядерной программы КНДР не раз рассматривалась в научной литературе с точки зрения классического реализма и неолиберального институционализма, однако представляется необходимым обратиться к более новым течениям в теории международных отношений, в частности, критическим исследованиям, к которым относится в том числе и теория секьюритизации.

Одним из дискуссионных моментов является вопрос об определении регионального комплекса безопасности применительно к рассматриваемой части мирового пространства. Сам Б. Бузан исходит из положения об азиатском "суперкомплексе" безопасности, признавая важную роль ядерного оружия в его конфигурации [13, с. 8]. При этом, как утверждает Р.Э. Келли, в понимании авторов теории США не рассматривались как участник регионального комплекса безопасности в Северо-Восточной Азии [17, с. 206-208].

Д. Лейк применил достижения теории секьюритизации к региональному комплексу безопасности в Северо-Восточной Азии, уже придя к выводу о влиянии на ситуацию внешнего игрока (а именно США) [18, с. 45-67]. При этом по выведенной им схеме КНДР взаимодействует со всеми акторами Северо-Восточной Азии, а посредником между Пхеньяном и Вашингтоном оказывается Япония.

Режим региональной безопасности в этой части мирового пространства рассматривался в научной литературе с точки зрения теории секьюритизации в диссертационной работе Пак Ки Чана [6, с. 7]. Исходя из тезиса об открытости процесса секьюритизации и его подверженности различным фракторам, автор, исследовавший комплекс региональной безопасности в Северо-Восточной Азии, пришёл к выводу о существовании двух во многом противоположных сил, определяющих формирование этого комплекса. С одной стороны, это Китай, который стремится к мирному разрешению межкорейского кондликта при сохранении правосубъектности КНДР de jure и de facto. С другой стороны, Япония активизирует свою роль в регионе, всё более жёстко реагируя на действия Пхеньяна. В то же время внешние игроки (в первую очередь, США и РФ) также участвуют в развитии комплекса. Кроме того, Пак Ки Чан сделал акцент на влиянии шестисторонних переговоров на процесс десекьюритизации северокорейской ядерной проблемы. Отмечается и многоаспектность проблемы: не стоит пренебрегать экономическим фактором при решении данной проблемы.

А.Л. Лукин делает акцент на том, что сами авторы теории расширяли территориальные рамки регионального комплекса безопасности до Восточной Азии как таковой [4, с. 10]. Имеется в виду слияние Северо-Восточной Азии и Юго-Восточной Азии в один Восточноазиатский региональный комплекс безопасности. В работе этого исследователя подчёркивается роль сдерживающего компонента ядерного оружия (в том числе и северокорейского) в развитии комплекса безопасности в этом регионе.

Б. Арди-Шартран из Университета Квебека в своём исследовании понимал под секьюритизацией политический инструмент, используемый именно северокорейским режимом с целью обеспечения собственного выживания [16, с. 7]. КНДР, как указывает канадский специалист, пытается создать образ внешнего врага, в частности США, для оправдания создания собственной ядерной программы. При этом применение такого инструмента, по мысли автора, реализуется при помощи пропаганды (в рамках которой и проявляются вышеописанные речевые акты). Б. Арди-Шартран утверждает, что существует связь между пропагандистскими высказываниями северокорейских элит и 
действиями КНДР на международной арене. Последние воспринимаются не как реакция на внешние раздражители, но как автономные действия, инициированные северокорейской стороной. Это и сказывается на отношениях Пхеньяна с Вашингтоном.

Несколько иным вариантом применения концепции Копенгагенской школы к указанной проблеме представляется рассмотрение секьюритизации сотрудничества в рамках межкорейского диалога [20, с. 11], предложенное М. Милани. Северокорейская ракетно-ядерная программа является одним из ключевых фракторов для выстраивания отношений между Пхеньяном и Сеулом, и Южная Корея при выстраивании взаимодействия с Северной исходила из посылки о необходимости денуклеаризации последней. Такой подход, демонстрируемый, по мнению автора, южнокорейским правительством, доказывал свою неэффрективность на протяжении достаточно долгого периода, что выражалось в многочисленных спадах в динамике отношений КНДР и Республики Корея.

Отечественные специалисты (С.А. Панарин, Н.С. Степанова) также рассматривали секьюритизацию как процесс, инициируемый КНДР. Приводя мнение авторов теории, по которому секьюритизация не обязательно исходит от одного актора, авторы, тем не менее концентрируются на понимании безопасности именно руководством КНДР. Они классифицируют Северную Корею как "крайний вариант модерного государства" [7, с. 86], сделав акцент на навязывании своих идеологических норм северокорейским режимом, стремящимся обеспечить собственное выживание.

Пэ Чон Юн и Мун Чун Ин, южнокорейские авторы, пришли к выводу о важности понятия суверенитета в рамках регионального комплекса безопасности в Северо-Восточной Азии, при этом важнейшим фрактором безопасности в этой части мирового пространства является военный [12, с. 7]. С их точки зрения, различные парадигмы МО не противоречат друг другу при изучении этого региона. А.Д. Воскресенский расценивает вклад этих исследователей как попытку добавления новых фракторов, влияющих на региональный комплекс безопасности $[\mathbf{1}$, с. $\mathbf{5 4}]$.

С точки зрения И.В. Дьячкова, ядерная программа КНДР оказывает и конструктивное влияние на развитие ситуации с безопасностью в Северо-Восточной Азии [3, с. 308]. Тем не менее это характерно лишь для отдельных этапов развития ввиду циклической природы развития конфликта, в то время как деструктивные фракторы проявляют себя на протяжении всего рассматриваемого периода. Конструктивное воздействие выражается в активизации работы различных международных форматов (в том числе и шестистороннего).

В.В. Горчаков отмечает, что разработка Северной Кореей ядерного оружия может спровоцировать обретение этого вида ОМУ другими странами ATP, в частности Японией и Южной Кореей, а также Тайванем [2, c. 66-68]. Это особенно актуально, учитывая наличие технологических возможностей у названных экономик, а также тот фракт, что дилемма обретения ЯО связана с наличием у них политической воли. Единственным решением проблемы автор считает ход в духе неолиберального институционализма, а именно созыв международной конференции по северокорейской ядерной проблеме в рамках многосторонней дипломатии, что в том числе и соответствует интересам Российской Федерации.

Встречались и публикации с критическим отношением к применению теории секьюритизации к северокорейской тематике [24, с. 111]. По мнению $\mathrm{X}$. Смит, теория секьюритизации воспроизводит парадигму мышления, характерную для времён "холодной войны", слишком упрощая анализ поведения государства. Аргументация тезиса о сомнительной применимости парадигмы секьюритизации состоит также и в многофракторности северокорейской политики и её быстро меняющейся природе. Среди других недостатков теории, с точки зрения автора, недостаточно убедительная доказательная база (что опровергается событиями уже XXI в.) Однако следует отметить, что рассматриваемая статья относится ещё к периоду до объявления КНДР частью "оси зла" и проведению Пхеньяном первого ядерного испытания, вследствие чего её актуальность заметно снижается.

Таким образом, в научной литературе можно выделить различные подходы к определению территориальных рамок регионального комплекса без- 
опасности: по мнению некоторых авторов, он охватывает лишь Корейский полуостров, с точки зрения других исследователей, его целесообразно расширить до Северо-Восточной либо Восточной Азии, кроме того, переход на ещё более высокий уровень приводит нас к понятию азиатского "суперколплекса" безопасности, характерного для АТР. Ещё одним пунктом, по которому позиции различных авторов могут расходиться, является вопрос о секьюритизирующем акторе: некоторые специалисты склонны рассматривать в качестве такового именно КНДР.

\section{Субрегиональный (под)комплекс безопасности в Северо-Восточной Азии}

Определение территориально-географических рамок затрагиваемого региона при всей дискуссионности этого вопроса имеет важное значение для успешного применения теории секьюритизации к ситуации с северокорейской ракетно-ядерной программой. С нашей точки зрения, необходимо отличать региональный колплекс безопасности (который относится к Восточной Азии в целом) и региональный подколплекс безопасности, или субрегиональный комплекс безопасности (в данном случае речь идёт о Северо-Восточной Азии). Территориально этот подкомплекс включает в себя Корейский полуостров (во многом являющийся его географическим ядром), Японию, КНР, Тайвань и Монголию, а также российский Дальний Восток. Северокорейская ракетно-ядерная проблема, по сути, занимает одно из ключевых мест среди угроз безопасности в этом субрегионе наряду с пограничными и территориальными спорами [10, с. 74]. Соответственно, решение этой проблемы являлось бы фактором, существенно изменившим субрегиональный и региональный комплексы безопасности. Включение Юго-Восточной Азии в этот подкомплекс безопасности, на наш взгляд, выглядело бы несколько неоправданным ввиду наличия в ЮВА собственных механизмов безопасности (с точки зрения ядерного нераспространения это, безусловно, зона, свободная от ядерного оружия, закреплённая в Бангкокском договоре 1995 г.) В Северо-Восточной Азии наблюдается и другой уровень развития ядерных технологий: практически у всех стран, кроме Монголии, имеется полный набор технологий ядерного топливного цикла, а ядерная энергетика играет значительную роль в экономической жизни этих стран. Считается, что получение ядерного оружия Японией или Республикой Корея связано лишь с вопросом политической воли. Кроме того, государства, которые активно взаимодействуют по вопросу северокорейской ядерной проблемы (Республика Корея, Япония, КНР) находятся именно в Северо-Восточной Азии, пусть последняя и находится на стыке интересов мирового треугольника официальных ядерных государств "Россия-КНР-США", выделенного А.Г. Арбатовым. В то же время это не отменяет наличие более крупного (уже не субрегионального) Восточноазиатского комплекса безопасности по Б. Бузану и О. Веверу, куда входит уже и ЮВА.

По утверждению Б. Бузана, традиционная концепция регионального комплекса безопасности сохраняет свою релевантность даже в новых глобальных условиях после окончания "холодной войны". Трансформация же этой концепции состоит в том, что к военно-политическим аспектам добавляются также экономические и экологические угрозы $[14, \mathbf{c .} 140]$. Это изменение также актуально и для ситуации с северокорейской ракетно-ядерной программой, в частности, с точки зрения экологии: подземные испытания ядерного оружия КНДР сопровождались землетрясениями и повышением уровня радиоактивности в том числе и в близлежащих регионах других стран [27].

Глобальные игроки, такие как Россия и США, непосредственно влияют на ситуацию с северокорейской ракетно-ядерной программой, что связано с их интересами как в субрегионе СВА, так и в АТР в целом. Проблема обладания Пхеньяном ЯО является лишь одним из пунктов на повестке американо-китайского противостояния. При әтом, несмотря на отсутствие прямой угрозы со стороны КНДР России, непредсказуемость поведения Пхеньяна осложняет ситуацию и для Москвы. 


\section{Ракетно-ядерная программа КНДР: этапы политизации и секьюритизации}

Проводя анализ ситуации с северокорейской ядерной программой с позиций теории Б. Бузана и О. Вевера, следует для начала определиться с применением используемой в рамках подобного анализа терминологии. Говоря о "секторах" безопасности, можно сделать вывод, что проблема находится на стыке военного и политического секторов. По логике секьюритизирующил акторол (т. е. инициатором процесса секьюритизации) здесь предстают США, а рефберентныли объектол - КНДР и их политика по созданию собственной ракетно-ядерной программы (что не отменяет взаимного характера рассматриваемых процессов, как будет показано ниже). В качестве так называемой аудитории выступают не просто государства Северо-Восточной Азии или Азиатско-Тихоокеанского региона, но мировое сообщество в целом, так как, несмотря на изначально региональный характер проблемы, развитие ракетно-ядерной программы КНДР стало представлять угрозу и внерегиональным акторам. Действия в отношении референтного объекта описываются установлением санкционного режима по резолюциям СБ ООН, а также автономными санкциями со стороны Вашингтона и некоторых других акторов.

Для более глубокого понимания проблемы с точки зрения теории секьюритизации необходимо обратиться к её исторической ретроспективе. Развитие ядерной программы КНДР началось ещё в 1950-х гг. На сосредоточение сил государства в области военной ядерной программы повлияла политика изоляционизма в условиях биполярного мира. Однако внимание мирового сообщества оказалось прикованным к ней только в начале 1990-х гг. Это, по сути, ознаменовало собой начало периода политизации проблемы. $K$ нему относится "первый ядерный кризис", начавшийся с отказа КНДР пустить инспекторов МАГАТЭ на свои ядерные объекты. За этим последовало впоследствии отозванное заявление КНДР о намерении выйти из Договора о нераспространении ядерного оружия. Естественно, такое развитие событий вызвало опасения касательно северокорейской ядерной программы, в первую очередь со стороны США. Вашингтон, поначалу всерьёз рассматривавший возможность нанесения ракетного удара по северокорейской территории, проявил активность на дипломатическом поле, что привело к заключению компромиссного Рамочного соглашения 21 октября 1994 г. Оно позволило на некоторое время coxpанить status quo в отношении военных разработок КНДР в ядерной cdpeре. Ещё во время "первого ядерного кризиса" усилия бывшего американского президента Дж. Картера послужили иллюстративным доказательством положения о важности роли личности в процессе строительства безопасности (а в данном случае этапа десекьюритизации).

Испытание КНДР ракеты "Пэктусан-1" в конце 1990-х гг. побудило администрацию Б. Клинтона начать разработку поправок к двустороннему соглашению с КНДР. Тем не менее приход к власти Дж. Буша-мл. в 2000 г. привёл к кардинальному пересмотру американской внешнеполитической линии в отношении Пхеньяна. К 2002 г. стало ясно, что "ядерная сделка" 1994 г. между КНДР и США не выполняется обеими сторонами. Ключевым моментом, представляющим aкm публичного объявления страны угрозой для мирового сообщества на современном этапе, следует считать послание Дж. Буша-мл. к Конгрессу от 29 января 2002 г., в котором утверждалось, что северокорейский режим "вооружается ракетами и оружием массового уничтожения" [25]. Кроме того, важным фрактором стало обвинение Пхеньяна администрацией Дж. Буша-мл. в создании ЯО на основе высокообогащённого урана. Впоследствии КНДР объявила о выходе из ДНЯО (это случилось в начале 2003 г.) и провела первое ядерное испытание в 2006 г.

Таким образом, для случая с ракетно-ядерной программой КНДР характерны оба этапа: политизация вопроса и последующая секьюритизация. На первом этапе было возможно договориться о заморозке ракетно-ядерной программы Пхеньяна в обмен на определённые уступки со стороны Запада, на втором после провала дипломатических усилий произошло обретение КНДР ядерного оружия. Интересно, что впоследствии оба эти этапа повторялись с определёнными оговорками: потепление отношений КНДР и США приводило к перезапуску переговорного процесса, а отсутствие прогресса в этом направлении оборачивалось дальнейшими взаимными обвинениями, которые при- 
водили к проведению очередных ракетных пусков или ядерных испытаний Пхеньяном и введению санкционного пакета против него. При этом циклический характер развития ситуации вокруг ракетно-ядерной программы Северной Кореи затрудняет определение хронологических рамок обоих этапов. Что касается стадии политизации вопроса, стоит отметить непосредственное влияние на восприятие КНДР и её ракетно-ядерной программы широкой общественностью со стороны СМИ и экспертных кругов. Происходила и продолжает происходить популяризация политического дискурса, в частности, презентации и обсуждение художественных книг по теме в ведущих учреждениях. Регулярным эпитетом в отношении северокорейской политики стало определение "агрессивная", из более показательных примеров использованное колумнистами издания "The Economist" словосочетание "параноидальное тоталитарное государство" [22]. В то же время это не отменяло рациональности КНДР, которая своими действиями, по мысли западного экспертного сообщества, пыталась выбить для себя международную помощь.

Кроме того, в американской риторике произошло и характерное для секьюритизации обращение к историческому опыту неудачной сделки 1990-х гг.: таким образом была показана недоговороспособность и ненадёжность Пхеньяна. Интересно, что по логике северокорейских властей уже в современности выход США из "ядерной сделки" 2015 г. с Ираном продемонстрировал ненадёжность Вашингтона как партнёра в аналогичной ситуации. В то же время даже соблюдение Пхеньяном международных норм может быть расценено как попытка добиться своих целей путём манипуляций.

Структурное понимание процесса секьюритизации в отношении КНДР выражается в использовании США бинарных оппозиций: с одной стороны, в текстах фигурирует понятие "цивилизованный мир", с другой стороны, президентская администрация США оперировала терминами "ось зла" и "государство-изгой" (англ. rogue state). Точкой невозврата можно назвать проведение КНДР первого ядерного испытания: если объявленный выход страны из ДНЯО можно было обратить, то фракт обретения ядерного оружия перевёл Северную Корею в принципиально другой статус с точки зрения режима ядерного нераспространения. Результатом являются санкционные нормы, закреплённые, в частности, в многочисленных Резолюциях СБ ООН, а также так называемые автономные санкции, распространяемые не только на КНДР, но и на третьих лиц, так или иначе контактирующих с этой страной в обход упомянутых резолюций.

Объявление КНДР державой из "оси зла" привело к пониманию этой страны в качестве угрозы не только со стороны иных акторов, но и самим северокорейским руководством. Это и побудило Пхеньян форсировать развитие собственной военной ядерной программы.

Неудивительно, что само существование КНДР является экзистенциальной угрозой для Республики Корея. В ст. III Конституции страны прописано, что территорией государства считается весь Корейский полуостров с прилежащими островами. Так, бывшая глава государства Пак Кын Хе заявляла, что проведение КНДР ядерных испытаний вызовет "эфрфект домино". Также она использовала dpразу "перейти Рубикон" по отношению к возможному ядерному взрыву КНДР [23]. Такие речевые акты, безусловно, соответствуют этапу секьюритизации. Тем не менее приход к власти Мун Чжэ Ина совпал с началом периода десекьюритизаџии северокорейской проблемы, что выразилось в проведении межкорейских саммитов.

Япония также исходит из того, что ракеты и ядерные испытания КНДР угрожают безопасности страны. Более того, Японией предпринимаются и конкретные меры по защите от возможного нападения со стороны Пхеньяна с использованием ядерного оружия, в частности, разворачиваются элементы противоракетной обороны [19, с. 103]. Также Токио (как и Сеул) полагается на концепцию "расширенного ядерного сдерживания" (англ. extended deterrence), или "ядерный зонтик" (позитивные гарантии безопасности) со стороны США. Несмотря на относительную сдержанность южнокорейских и японских официальных лиц в формулировках, ясно, что северокорейская ракетно-ядерная программа воспринимается обеими странами как угроза ввиду ряда фракторов (непосредственная географическая близость, идеологическое противостояние с Пхеньяном, союзные отношения с Вашингтоном). Из этого 
можно сделать вывод о применимости концепции "регионального комплекса безопасности" к рассматриваемой ситуации.

Важное значение в данной парадигме имеет роль личности, что можно доказать на примере перехода во внешнеполитической линии США в отношении КНДР со сменой администрации Б. Клинтона на администрацию Дж. Буша-мл. В то же время перемены в этой связи происходили и в период президентства одного и того же человека (Д. Трампа), когда максимальное ужесточение санкционного давления сменилось заявлениями о сотрудничестве. Изменение позиции американского руководства по проблеме (а изначально Д. Трамп стремился к роли посредника в межкорейских переговорах) стало ключевой предпосылкой для определённого прорыва на северокорейском направлении. Переломным моментом стал сингапурский саммит 12 июня 2018 г., на котором была достигнута договорённость о поэтапном свёртывании северокорейской ракетно-ядерной программы (перед этим была заключена межкорейская Пханмунджомская декларация, в которой также содержался пункт о постепенном отказе Пхеньяна от ЯО). Отсутствие ядерных и ракетных испытаний на протяжении второй половины 2018 г. - начала 2019 г. позволило сторонам договориться о проведении второй встречи на высшем уровне во Вьетнаме.

Не следует забывать и о ценностной природе процесса секьюритизации: использование обеими сторонами бинарных оппозиций (в том числе в идеологическом плане: демократия и капитализм противопоставляются плановой экономике и социализму) влияет на подготовку общественного мнения и настраивание его против определённого государства, оправдывая тем самым действия, которые будут предприняты против него. Ракетно-ядерная программа КНДР становится для самой страны средством самозащиты, а для иных игроков возможностью обосновать собственную линию на изоляцию Пхеньяна и агрессивную риторику по отношению к Северной Корее.

Впрочем, в последние несколько лет территориальные рамки проблемы несколько расширились: по свидетельству ряда американских учёных, межконтинентальные баллистические ракеты, испытанные Пхеньяном в 2017 г., могут достичь материковой части США.

События последних лет лишь подтверждают тезис о маятниковом характере развития ситуации вокруг северокорейской ракетно-ядерной программы. В частности, успешный саммит Д. Трампа и Ким Чен Ына 12 июня 2018 г. в Сингапуре, перед которым Пхеньян произвёл демонстративный демонтаж ядерного полигона Пхунгери, увенчался достижением договорённостей о постепенной денуклеаризации Корейского полуострова. Вьетнамский саммит 27-28 февраля 2019 г., напротив, был оценён как провальный и сопровождался сообщениями о восстановлении КНДР ракетного полигона Сохэ. Впрочем, 30 июня 2019 г. состоялась импровизированная встреча двух лидеров на границе двух Корей (которая носила больше символическое значение).

Последовательная стигматизация такого рода сподвигла руководство КНДР на практические шаги по форсированию ракетной и ядерной программ, дала возможность обосновать курс на обретение ядерного оружия в политической риторике. Для Пхеньяна создание ядерного оружия стало проектом государственной важности. При этом специально подчёркивалось, что ядерные вооружения необходимы стране исключительно в целях самозащиты от агрессивных действий США и их союзников по Азиатско-Тихоокеанскому региону (в первую очередь, Японии и Республики Корея). Разумеется, значение, придаваемое Северной Кореей своей ядерной программе не только во внешней, но и во внутренней политике (связанное с культивированием образа врага и необходимости противостоять ему в рамках идеологической концепции "сонгун"), несравненно повышает цену отказа от ЯО.

В итоге произошла своеобразная интериоризация образа ядерной державы, что вылилось в принятие поправок в Конституцию страны в апреле 2012 г., когда КНДР официально объявила себя ядерным государством. Такие изменения на конституционном уровне подтверждают тезис о важности самого статуса ядерной державы для северокорейских элит.

Соответственно, представляется возможным выделить отдельные этапы развития северокорейской ракетно-ядерной программы с точки зрения теории 
секьюритизации (разумеется, подобная периодизация носит в достаточной степени условный характер):

1) 1992-1994 гг. ("первый ядерный кризис"): этап политизации и последующей секьюритизации;

2) 1994-2001 гг. (период действия, пусть и номинального, Рамочного соглашения): этап десекьюритизации;

3) 2001-2003 гг. (причисление КНДР к "оси зла", выход её из ДНЯО): этап секьюритизации;

4) 2003-2006 гг. (начало переговоров в шестистороннем формате до первого ядерного испытания): этап десекьюритизации;

5) 2006-2017 гг. (проведение первого и последующих ядерных испытаний, остановка шестистороннего переговорного процесса, легитимация ядерного статуса на конституционном уровне): этап секьюритизации;

6) 2018 - по настоящее время (заморозка ракетных и ядерных испытаний, демонтаж полигона Пхунгери, проведение двусторонних саммитов с Южной Кореей и США, объявление политики параллельного развития "пёнчжин"): этап десекьюритизации.

\section{Выводы}

Несмотря на описанную выше критику теории секьюритизации, представляется, что использование положений таковой в отношении северокорейской ракетно-ядерной программы вполне оправдано и успешно в связи с рядом причин. Во-первых, это военно-политическая природа угрозы, определённая Соединёнными Штатами (как за счёт включения КНДР в "ось зла" в 2002 г., так и за счёт появления недавних сообщений о возможности достижения территории США северокорейскими МБР). Во-вторых, это изначально региональный характер угрозы, что вписывается в концепт "регионального комплекса безопасности" как на субрегиональном (Северо-Восточная Азия), так и на более высоком (Азиатско-Тихоокеанский регион) уровне. Важность северокорейской ракетно-ядерной программы для повестки дня в области безопасности стран Северо-Восточной Азии (Японии, Южной Кореи, отчасти КНР) доказывает состоятельность регионального подкомплекса безопасности как социального конструкта (как его и понимали авторы теории секьюритизации).

Налицо "пульсирующий", маятниковый характер развития северокорейской ракетно-ядерной программы, когда этапы активизации ракетных испытаний и ядерных взрывов сменяются на готовность страны к сотрудничеству в многосторонних (шестисторонние переговоры) и двусторонних (саммиты Ким Чен Ына и Д. Трампа) форматах. Этот феномен может объясняться с точки зрения теории секьюритизации не только объективными технологическими циклами развития военной ядерной программы КНДР, но и колебаниями внешнеполитической линии США в отношении Пхеньяна: недавнее потепление в двусторонних контактах предварялось заявлениями Д. Трампа о скором прорыве в отношении с КНДР при условии начала процесса её ядерного разоружения. Это взаимовлияние представлений элит двух стран о проблеме во многом определяет динамику рассматриваемой ситуации. Более того, такой "пульсирующий" характер развития северокорейской ракетно-ядерной программы сказывается и на ситуации в региональном подкомплексе безопасности в Северо-Восточной Азии в целом.

В то же время участие Вашингтона в процессе (де)секьюритизации северокорейской ядерной программы отнюдь не уникально: другие игроки, прежде всего региональные, также своими действиями (в т.ч. за счёт выражения официальной позиции) могут непосредственно влиять на динамику развития событий. В этой связи важно иметь в виду, что недавние достижения на межкорейском направлении (имеется в виду подписание Пханмунджомской декларации) предшествовали достижению договорённости о проведении саммита США и КНДР. Мун Чжә Ин, заявлявший о недопустимости нанесения ядерного удара любой из сторон, сыграл большую роль в достижении разрядки в рассматриваемой ситуации. Китай, сохранявший тесный контакт с Пхеньяном на протяжении всего переговорного процесса последнего с США, также оказывал прямое воздействие на фрормирование северокорейской позиции. 
Таким образом, нельзя отрицать, что процесс секьюритизации является двусторонним (и даже многосторонним). Признаки этапов политизации и секьюритизации проблемы наблюдались в политике не только КНДР и США, но и их партнёров по региону (Китай с одной стороны и Республика Корея плюс Япония с другой). Принимая политические решения в отношении собственной ракетно-ядерной программы, КНДР также исходит из недружественности США и их азиатских партнёров по отношению к себе, открыто объявляя их идеологическими противниками. Естественно, что для КНДР ракетно-ядерная программа является своеобразной гарантией ненападения со стороны вышеупомянутых акторов. Тот же тезис можно считать верным и в отношении обратного процесса: готовность стран на уступки, проявляемая одновременно, приводит к определённому прогрессу. В частности, он выразился в последнее время в двусторонних встречах лидеров Республики Корея и КНДР, США и КНДР соответственно, а также заморозке ядерных и ракетных испытаний Пхеньяном.

Наконец, говоря о прогнозе развития ситуации в краткосрочной перспективе, длительность текущего периода десекьюритизации зависит от ряда переменных. В первую очередь, речь идёт о том, реактивную или проактивную позицию займёт администрация Дж. Байдена на северокорейском направлении, и каковы будут практические шаги её в этом отношении. Смена правительства в Японии с уходом с поста премьера С. Абэ и приходом к власти Е. Суги не слишком повлияла на активность КНДР в рассматриваемой сфрере. Впрочем, предстоящие выборы президента в Южной Корее могут спровоцировать определённые шаги со стороны северокорейского руководства. Кроме того, достижение нового уровня технологического развития в ракетной или ядерной сферах также может сподвигнуть Пхеньян на новые испытания. Но нельзя отрицать, что северокорейские элиты будут учитывать возможные последствия подобных действий, рассчитывая на конкретную реакцию других игроков.

\section{Литература}

1. Воскресенский А.Д. Концепции регионализации, региональных подсистем, региональных комплексов и региональных трансформаций в современных международных отношениях // Сравнительная политика. 2012. № 2 (8). С. 30-58. DOI. org/10.18611/2221-3279-2012-3-2(8)-30-58.

2. Горчаков В.В. Проблемы ядерной безопасности в Северо-Восточной Азии // Таможенная политика России на Дальнем Востоке. 2016. № 4 (77). С. 62-69.

3. Дьячков И.В. Влияние ядерной проблемы КНДР на безопасность в Северо-Восточной Азии // Вестник ТГУ. 2012. № 5. С. 308-314.

4. Лукин А.Л. Теория комплексов региональной безопасности и Восточная Азия // Ойкумена. Регионоведческие исследования. 2011. № 2(17). С. 7-19.

5. Нелидов В.В. Региональная безопасность в Северо-Восточной Азии и треугольник "Россия-США-Япония" // Российский совет по международным делам [Электронный ресурc]. URL: https:// russiancouncil.ru/papers/Northeast-Security-Policybrief16-Ru. pdf (дата обращения: 31.07.2020).

6. Пак Ки Чан. Корейский полуостров в региональном и глобальном измерениях безопасности. Автореферат диссертации на соискание ученой степени кандидата политических наук по спещиальности 23.00.04. Москва: МГИМО, 2009. 29 с.

7. Панарин С.А., Степанова Н.С. Мировоззренческие основы представлений о безопасности руководства КНДР // Восток (Oriens). 2015. № 6. С. 83-97.

8. Победаш Д.И. Международные режимы нераспространения ядерного оружия. Екатеринбург: Издательство Уральского университета, 2010. 30 с.

9. Тамбовцева М.А. Теоретический подход Копенгагенской школы к обеспечению международной безопасности: основные положения теории секьюритизации // Исторические, философские, политические и юридические науки, культурология и искусствоведение. Вопросы теории и практики. 2017. № 9(83). С. 185-187.

10. Юрковский А.В. Северо-Восточная Азия: некоторые проблемы международных отношений // Сибирский юридический вестник. 2006. № 1. С. 74-78.

11. Ядерный мир: новые вызовы режиму ядерного нераспространения // Под. ред. Е.Б. Михайленко. Екатеринбург: Издательство Уральского федерального университета, 2017. 432 с. 
12. Bae Jong-Yun, Moon Chung-in. Unraveling the Northeast Asian Regional Security Complex: Old Patterns and New Insights // Korean Journal of Defense Analysis. 2005. Vol. 17. Issue 2. P. 7-34. https:// doi.org/10.1080/10163270509464082.

13. Buzan B. Asia: A Geopolitical Reconfiguration // IFRI - Institut français des relations internationales [Электронный pecypc]. URL: https:// www.ifri.org/sites/default/ files/atoms/files/barrybuzanengpe22012.pdf (дата обращения: 31.07.2020).

14. Buzan B. Regional Security Complex Theory in the Post-Cold War World // Theories of New Regionalism. International Political Economy Series. Ed. by F. Söderbaum, T.M. Shaw. London: Palgrave Macmillan, 2003. P. 140-159. https:// doi. org/10.1057/9781403938794_8.

15. Floyd R., Croft S. European non-traditional security theory: from theory to practise // Geopolitics, History, and International Relations. 2011. No 3(2). P. 152-179.

16. Hardy-Chartrand B. La construction de la menace et la sécuritisation en Corée du Nord: effets sur la politique étrangère // Mémoire présenté comme exigence partielle de la maîtrise en science politique. Montréal: Université du Québec à Montréal, 2012. 123 p.

17. Kelly R.E. Security Theory in the 'New Regionalism' // International Studies Review. 2007. No 9/2. P. 197-229.

18. Lake D. Regional Security Complexes: A Systems Approach // Regional Orders: Building Security in A New World. Ed. by D. Lake, P. Morgan. University Park: Pennsylvania State University Press. 1997. P. 45-67.

19. Michishita N. Japan's Response to Nuclear North Korea // Joint U.S.-Korea Academic Studies. Ed. by G. Rozman. 2012. Vol. 23. P. 100-112.

20. Milani M. Securitizing Cooperation: Nuclear Politics and Inter-Korean Relations // North Korean Review. 2018. Vol. 14. No. 1. P. 11-29.

21. Potts M. Is North Korea a Rational Actor? The Wrong and Right Questions to Ask // Sino-NK. December 05, 2013 [Электронный ресурc]. URL: https:// sinonk.com/2013/12/05/ is-north-korea-a-rational-actor-the-wrong-and-right-questions-to-ask/ (дата обращения: 31.07.2020).

22. Prisoner's dilemma meets Turing test // The Economist. May 27th 2010. [Электронный ресурc] URL: https:// www.economist.com/democracy-in-america/2010/05/27/ prisoners-dilemma-meets-turing-test (дата обращения: 31.07.2020).

23. S. Korean Leader Warns of 'Nuclear Domino' if North Conducts Test // Nuclear Threat Initiative. May 30, 2014 [Электронный pecypc]. URL: https:// www.nti.org/gsn/ article/south-korean-president-warns-regional-domino-effect-if-north-detonates-nukedevice/ (дата обращения: 31.07.2020).

24. Smith H. Bad, Mad, Sad or Rational Actor? Why the 'Securitization' Paradigm Makes for Poor Policy Analysis of North Korea // International Affairs (Royal Institute of International Affairs 1944-). 2000. Vol. 76. No. 1 (Jan., 2000). P. 111-132.

25. Text of President Bush's 2002 State of the Union Address // The Washington Post. Jan. 29, 2002 [Электронный ресурc]. URL: http:// www.washingtonpost.com/wp-srv/ onpolitics/transcripts/sou012902.htm (дата обращения: 31.07.2020).

26. Wæver O. Securitization and Desecuritization // On Security. Ed. by R.D. Lipschutz. Columbia University Press, 1995. P. 46-87.

27. 朝鲜核试验已造成严重放射污染? // Deutsche Welle. 21.11.2017 [Электронный pecypc]. URL: https:// www.dw.com/zh/\%E6\%9C\%9D $\% \mathrm{E} 9 \% \mathrm{~B} 2 \% 9 \mathrm{C} \% \mathrm{E} 6 \% \mathrm{~A} 0 \% \mathrm{~B} 8 \% \mathrm{E} 8 \%$ AF\%95\% $\mathrm{E} 9 \% \mathrm{AA} \% 8 \mathrm{C} \% \mathrm{E} 5 \% \mathrm{~B} 7 \% \mathrm{~B} 2 \% \mathrm{E} 9 \% 80 \% \mathrm{~A} 0 \% \mathrm{E} 6 \% 88 \% 90 \% \mathrm{E} 4 \% \mathrm{~B} 8 \% \mathrm{~A} 5 \% \mathrm{E} 9 \% 87 \% 8$ $\mathrm{D} \% \mathrm{E} 6 \% 94 \% \mathrm{BE} \% \mathrm{E} 5 \% \mathrm{~B} 0 \% 84 \% \mathrm{E} 6 \% \mathrm{~B} 1 \% \mathrm{~A} 1 \% \mathrm{E} 6 \% 9 \mathrm{~F} \% 93 / \mathrm{a}-41456542$ (дата обращения: 14.02.2021).

\section{Транслитерация по ГОСТ 7.79-2000 система Б}

1. Voskresenskij A.D. Kontseptsii regionalizatsii, regional'nykh podsistem, regional'nykh kompleksov i regional'nykh transformatsij v sovremennykh mezhdunarodnykh otnosheniyakh // Sravnitel'naya politika. 2012. № 2 (8). S. 30-58. DOI.org/10.18611/22213279-2012-3-2(8)-30-58.

2. Gorchakov V.V. Problemy yadernoj bezopasnosti v Severo-Vostochnoj Azii // Tamozhennaya politika Rossii na Dal'nem Vostoke. 2016. № 4 (77). S. 62-69.

3. D'yachkov I.V. Vliyanie yadernoj problemy KNDR na bezopasnost' v Severo-Vostochnoj Azii // Vestnik TGU. 2012. № 5. S. 308-314.

4. Lukin A.L. Teoriya kompleksov regional'noj bezopasnosti i Vostochnaya Aziya // Ojkumena. Regionovedcheskie issledovaniya. 2011. № 2(17). S. 7-19.

5. Nelidov V.V. Regional'naya bezopasnost' v Severo-Vostochnoj Azii i treugol'nik "Rossiya-SSHA-YAponiya" // Rossijskij sovet po mezhdunarodnym delam [Ehlektronnyj resurs]. URL: https:// russiancouncil.ru/papers/Northeast-Security-Policybrief16-Ru.pdf (data obrashheniya: 31.07.2020).

6. Pak Ki Chan. Korejskij poluostrov v regional'nom i global'nom izmereniyakh bezopasnosti. Avtoreferat dissertatsii na soiskanie uchenoj stepeni kandidata politicheskikh nauk po spetsial'nosti 23.00.04. Moskva: MGIMO, 2009. 29 s. 
7. Panarin S.A., Stepanova N.S. Mirovozzrencheskie osnovy predstavlenij o bezopasnosti rukovodstva KNDR // Vostok (Oriens). 2015. № 6. S. 83-97.

8. Pobedash D.I. Mezhdunarodnye rezhimy nerasprostraneniya yadernogo oruzhiya. Ekaterinburg: Izdatel'stvo Ural'skogo universiteta, 2010. $30 \mathrm{~s}$.

9. Tambovtseva M.A. Teoreticheskij podkhod Kopengagenskoj shkoly k obespecheniyu mezhdunarodnoj bezopasnosti: osnovnye polozheniya teorii sek'yuritizatsii // Istoricheskie, filosofskie, politicheskie i yuridicheskie nauki, kul'turologiya i iskusstvovedenie. Voprosy teorii i praktiki. 2017. № 9(83). S. 185-187.

10. YUrkovskij A.V. Severo-Vostochnaya Aziya: nekotorye problemy mezhdunarodnykh otnoshenij // Sibirskij yuridicheskij vestnik. 2006. № 1. S. 74-78.

11. YAdernyj mir: novye vyzovy rezhimu yadernogo nerasprostraneniya // Pod. red. E.B. Mikhajlenko. Ekaterinburg: Izdatel'stvo Ural'skogo federal'nogo universiteta, 2017. 432 s.

12. Bae Jong-Yun, Moon Chung-in. Unraveling the Northeast Asian Regional Security Complex: Old Patterns and New Insights // Korean Journal of Defense Analysis. 2005. Vol. 17. Issue 2. P. 7-34. https:// doi.org/10.1080/10163270509464082.

13. Buzan B. Asia: A Geopolitical Reconfiguration // IFRI - Institut français des relations internationales [Ehlektronnyj resurs]. URL: https:// www.ifri.org/sites/default/files/ atoms/files/barrybuzanengpe22012.pdf (data obrashheniya: 31.07.2020).

14. Buzan B. Regional Security Complex Theory in the Post-Cold War World /I Theories of New Regionalism. International Political Economy Series. Ed. by F. Söderbaum, T.M. Shaw. London: Palgrave Macmillan, 2003. P. 140-159. https:// doi. org/10.1057/9781403938794_8.

15. Floyd R., Croft S. European non-traditional security theory: from theory to practise // Geopolitics, History, and International Relations. 2011. No 3(2). P. 152-179.

16. Hardy-Chartrand B. La construction de la menace et la sécuritisation en Corée du Nord: effets sur la politique étrangère // Mémoire présenté comme exigence partielle de la maîtrise en science politique. Montréal: Université du Québec à Montréal, 2012. 123 p.

17. Kelly R.E. Security Theory in the 'New Regionalism' // International Studies Review. 2007. No 9/2. P. 197-229.

18. Lake D. Regional Security Complexes: A Systems Approach // Regional Orders: Building Security in A New World. Ed. by D. Lake, P. Morgan. University Park: Pennsylvania State University Press. 1997. P. 45-67.

19. Michishita N. Japan's Response to Nuclear North Korea // Joint U.S.-Korea Academic Studies. Ed. by G. Rozman. 2012. Vol. 23. P. 100-112.

20. Milani M. Securitizing Cooperation: Nuclear Politics and Inter-Korean Relations // North Korean Review. 2018. Vol. 14. No. 1. P. 11-29.

21. Potts M. Is North Korea a Rational Actor? The Wrong and Right Questions to Ask // Sino-NK. December 05, 2013 [Ehlektronnyj resurs]. URL: https:// sinonk.com/2013/12/05/ is-north-korea-a-rational-actor-the-wrong-and-right-questions-to-ask/ (data obrashheniya: 31.07 .2020$)$.

22. Prisoner's dilemma meets Turing test // The Economist. May 27th 2010. [Ehlektronnyj resurs] URL: https:// www.economist.com/democracy-in-america/2010/05/27/prisoners-dilemma-meets-turing-test (data obrashheniya: 31.07.2020).

23. S. Korean Leader Warns of 'Nuclear Domino' if North Conducts Test // Nuclear Threat Initiative. May 30, 2014 [Ehlektronnyj resurs]. URL: https:// www.nti.org/gsn/article/south-korean-president-warns-regional-domino-effect-if-north-detonates-nuke-device/ (data obrashheniya: 31.07.2020).

24. Smith H. Bad, Mad, Sad or Rational Actor? Why the 'Securitization' Paradigm Makes for Poor Policy Analysis of North Korea // International Affairs (Royal Institute of International Affairs 1944-). 2000. Vol. 76. No. 1 (Jan., 2000). P. 111-132.

25. Text of President Bush's 2002 State of the Union Address // The Washington Post. Jan. 29, 2002 [Ehlektronnyj resurs]. URL: http:// www.washingtonpost.com/wp-srv/onpolitics/transcripts/sou012902.htm (data obrashheniya: 31.07.2020).

26. Wæver O. Securitization and Desecuritization // On Security. Ed. by R.D. Lipschutz. Columbia University Press, 1995. P. 46-87.

27. 朝鲜核试验已造成严重放射污染? // Deutsche Welle. 21.11.2017 [Ehlektronnyj resurs]. URL: https:// www.dw.com/zh/\%E6\%9C\%9D\%E9\%B2\%9C\%E6\%A0\%B8\%E8\%A F\%95\%E9\%AA\%8C\%E5\%B7\%B2\%E9\%80\%A0\%E6\%88\%90\%E4\%B8\%A5\%E9\%87\%8D \% $6 \% 94 \% \mathrm{BE} \% \mathrm{E} 5 \% \mathrm{~B} 0 \% 84 \% \mathrm{E} 6 \% \mathrm{~B} 1 \% \mathrm{~A} 1 \% \mathrm{E} 6 \% 9 \mathrm{~F} \% 93 / \mathrm{a}-41456542$ (data obrashheniya: 14.02.2021) 
Торопчин Г. В. Северокорейская ракетно-ядерная программа с точки зрения теории секьюритизации.

В статье рассматривается ракетно-ядерная программа КНДР с точки зрения теории секьюритизации Б. Бузана и О. Вевера. Автор использует положения теории секьюритизации для объяснения предпосылок, подтолкнувших Пхеньян к разработке ракетно-ядерной программы в рамках Северо-Восточной Азии как субрегионального комплекса безопасности. Выделяются "секьюритизирующий актор", "референтный объект" и "аудитория" в соответствии с методологией Копенгагенской школы. Исследуется влияние секьюритизации на официальные позиции государств по этому вопросу, восприятие проблемы широкой общественностью. В заключении проводится периодизация развития ракетно-ядерной программы КНДР, подчёркиваются её "пульсирующий", маятниковый характер, многосторонняя природа процесса и взаимовлияние актов, составляющих его содержание.

Ключевые слова: ракетно-ядерная програлма КНДР, теория секьюритизации, "региональный колплекс безопасности"

Toropchin G. V. North Korean Missile and Nuclear Programme from the Securitisation Theory Standpoint.

The given article is dedicated to scrutinising North Korean missile and nuclear programmes from the standpoint of securitisation theory advocated by B. Buzan and O. Wæver. The author utilises various ideas within the securitisation theory to explain reasons which invoked the development of Pyongyang's missile and nuclear programme in Northeast Asia as a subregional security complex. The paper marks out the "securitising actor", "referent object" and "audience" in accordance with the described methodology. The work features examples of how securitisation influences countries' official positions on the international arena and the perception of North Korean nuclear programme by the general public. Based on the conclusions drawn, the research provides a periodisation of North Korean nuclear and missile programme evolvement, which unravels its "pulsing", pendulous nature; its multilateral gist, as well as mutual influence of the acts which compose it.

Key words: North Korean missile and nuclear programmes, securitisation theory, regional security complex

Для цитирования: Торопчин Г. В. Северокорейская ракетно-ядерная программа с точки зрения теории секьюритизации // Ойкумена. Регионоведческие исследования. 2021. № 2. C. 117-129. DOI: 10.24866/1998-6785/2021-2/117-129

For citation: Toropchin G. V. North Korean Missile and Nuclear Programme from the Securitisation Theory Standpoint // Ojkumena. Regional researches. 2021. № 2. P. 117-129. DOI: $10.24866 / 1998-6785 / 2021-2 / 117-129$ 